\title{
Spring frost and decay fungi are implicated in suppressing aspen re-growth following partial cleaning in juvenile stands
}

\author{
Jane M. WolKeN*, Victor J. LIEFFERS, Simon M. LANDHÄUSSER, Tara MULAK \\ Centre for Enhanced Forest Management, Department of Renewable Resources, University of Alberta, 4-42 Earth Sciences Building, \\ Edmonton, AB, T6G 2E3, Canada
}

(Received 2 February 2009; accepted 30 April 2009)

Keywords:

aspen /

Populus tremuloides /

partial-cleaning /

frost /

Armillaria root rot

\begin{abstract}
- Aspen (Populus tremuloides Michx.) regenerates at high densities following manual cleaning.

- Ten-year-old stands located near Lac La Biche and Peace River, Alberta were manually cleaned to three densities $\left(0,500\right.$ or 1500 stems ha $\left.^{-1}\right)$ at three times (bud set, dormancy or bud flush) to test the hypothesis that maintaining residual aspen reduces regeneration.

- At Lac La Biche up to $98 \%$ of the aspen regeneration died in the partially-cleaned plots compared to $67 \%$ at Peace River five years post-treatment. A spring frost in the second growing season at Lac La Biche is hypothesized to be the inciting factor predisposing the stump sprouts to infection by decay fungi such as Armillaria root rot, resulting in reduced density and height of the aspen regeneration at Lac La Biche relative to Peace River. Drought and ungulate herbivory provided additional stresses. The high mortality of aspen regeneration at Lac La Biche shifted the understory regeneration from aspen to balsam poplar (Populus balsamifera L.).

- These results indicate that maintaining $1500 \mathrm{stems} \mathrm{ha}^{-1}$ of residual aspen will not effectively control the re-sprouting of aspen; however, the vulnerability of aspen regeneration to spring frost and other stressors can nearly eradicate the re-growth of aspen.
\end{abstract}

Résumé - Le gel de printemps et la pourriture fongique sont impliqués dans la suppression de la repousse des trembles rejetant après un nettoiement partiel dans des peuplements juvéniles.

- Le tremble (Populus tremuloides Michx.) se régénère à haute densité à la suite d'un nettoiement manuel.

- Des peuplements âgés de dix ans situés près de Lac La Biche et de Peace River, en Alberta, ont été nettoyés manuellement à trois densités $\left(0,500\right.$ ou 1500 tiges ha $\left.^{-1}\right)$ à trois moments (bourgeon formé, dormance des bourgeons ou débourrement) pour tester l'hypothèse que le maintien de trembles résiduels réduit la régénération.

- Au Lac La Biche, on constate jusqu'à $98 \%$ de mortalité de la régénération du tremble dans les parcelles partiellement nettoyées par rapport au $67 \%$ de Peace River cinq ans après le traitement. Un gel printanier dans la deuxième saison de croissance, à Lac La Biche est supposé être le facteur prédisposant les pousses de la souche à être infectées par les pourritures fongiques comme Armillaria (pourriture des racines), ce qui réduit la densité et la hauteur de la régénération du tremble à Lac La Biche par rapport à Peace River. La sécheresse et les ongulés herbivores fournissent un stress supplémentaire. L'importante mortalité de la régénération du tremble à Lac La Biche modifie la régénération du sous-étage du tremble en peuplier baumier (Populus balsamifera L.).

- Ces résultats indiquent que le maintien de 1500 tiges $^{-1} \mathrm{a}^{-1}$ de trembles résiduels ne contrôlera pas efficacement les rejets du tremble, cependant la vulnérabilité de la régénération des trembles au gel de printemps et aux autres facteurs de stress peut presque éliminer le recru des trembles.

\section{INTRODUCTION}

In the management of regenerating mixtures of aspen (Populus tremuloides Michx.) and white spruce (Picea glauca

*Corresponding author: jane.wolken@ualberta.ca
(Moench) A. Voss) the density of aspen regeneration commonly needs to be controlled to maintain reasonable growth rates of the spruce (Peterson and Peterson, 1995). Partial harvesting had been proposed as a means to reduce the density of aspen regeneration (Doucet, 1989; Huffman et al., 1999; David 
et al., 2001; Mulak et al., 2006), as suckering is thought to be suppressed by the residual canopy through the translocation of auxin from the residual stems (Eliasson, 1971). The timing of cleaning has also been identified as an important variable determining both the density (Steneker, 1976; Bates et al., 1993) and height growth (Bella, 1986) of aspen regeneration.

To test the hypothesis that the partial cleaning (defined as the removal of juvenile trees) of aspen reduces the density of aspen regeneration 10-yr-old juvenile aspen stands were manually cleaned to three different residual densities $(0,500$

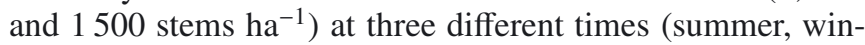
ter and spring) corresponding to different phenological stages of aspen (bud set, dormancy and bud flush) between August 2003 and June 2004 (Mulak et al., 2006). This field trial was replicated regionally with one study location in eastern Alberta near Lac La Biche and a second location approximately $500 \mathrm{~km}$ away in northwestern Alberta near Peace River. Following the growing season in 2004 there were marked decreases in the density of aspen regeneration with increasing density of residual aspen and a decrease in sprout height after spring cleaning across all sites. Overall the density of aspen regeneration was deemed to be too high for these treatments to be a practical tool for vegetation management (Mulak et al., 2006).

When revisiting the treatment plots near Lac La Biche in 2008 it was observed that the aspen regeneration were either dead or growing poorly, especially in the 500 and 1500 stems $\mathrm{ha}^{-1}$ residual density treatments; the mortality of the aspen regeneration in several of the completely-cleaned treatment plots was also exceptionally high at Lac La Biche. This large reduction in the density of the aspen regeneration prompted a re-measurement of the treatment plots in both study locations 5 y post-treatment. The overall objective of the current paper was to evaluate the impact of the cleaning treatments on the density of aspen regeneration $5 \mathrm{y}$ post-treatment. The specific objectives were to: (i) determine whether the density of aspen regeneration in areas with residual aspen was now low enough to justify prescribing this method as a vegetation management tool; and (ii) investigate potential factors accounting for differences in the regeneration between the two study locations.

\section{METHODS}

\subsection{Study area and experimental design}

This study was established in the fall of 2003 and spring of 2004 in approximately 10 -year-old aspen-dominated cutblocks. The original experiment was a $2 \times 3 \times 3$ block factorial design with two study locations (Lac La Biche and Peace River), three levels of residual density of aspen after cleaning (completely-cleaned to 0 stems ha $\mathrm{ha}^{-1}$

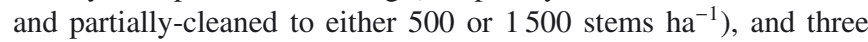
times of cleaning (bud set, dormancy and bud flush). Five replicate cutblocks were located northeast of Lac La Biche (54 $46^{\prime} \mathrm{N} 111^{\circ}$ $59^{\prime} \mathrm{W}$ ) and five northwest of Peace River (56 $14^{\prime} \mathrm{N} 117^{\circ} 17^{\prime} \mathrm{W}$ ). Mulak et al. (2006) provide detailed descriptions of the study area locations and layout of treatment plots.

\subsection{Field measurements and climate indices}

In the late summer of 2008 the 10 cutblocks were re-measured. In the original analysis one of the Peace River replicates was excluded from the analysis because the residual trees within these plots were much larger than in the other replicate cutblocks (Mulak et al., 2006). As the differences between the original 4 Peace River cutblocks and the excluded cutblock were smaller in 2008 , this replicate was included in the re-measurement.

Measurements of the residual trees in each plot in 2008 included the diameter at breast height $(\mathrm{DBH} ; \mathrm{cm})$ of the 10 residual trees clustered around the plot centre that had been marked and measured in 2004. The height $(\mathrm{m})$ of three of these residual trees was also measured.

In 2008, aspen and balsam poplar (Populus balsamifera L.) regeneration were measured in a grid of nine $10 \mathrm{~m}^{2}$ circular regeneration sub-plots centered in each treatment plot. The total number and height $(\mathrm{cm})$ of the tallest aspen and balsam poplar stems were recorded in each quarter of the sub-plots. To estimate the proportion of the regeneration that were stump sprouts, the first 10 aspen stems encountered in each sub-plot were distinguished as either root suckers or as stump sprouts.

In addition to stand characteristics, we also investigated insect defoliation, disease and extreme weather events as potential factors that could have affected the regeneration of aspen on these sites. Insect defoliation data for the study areas collected from aerial surveys was obtained from Alberta Sustainable Resource Development for the 2000 to 2008 survey years. Monthly climate data were obtained from Environment Canada weather stations located $80 \mathrm{~km}$ (Conklin LO weather station) and $25 \mathrm{~km}$ (Lac La Biche climate station) from the Lac La Biche plots, and $30 \mathrm{~km}$ (Peace River A weather station) from the Peace River plots to look at the occurrence of temperature and drought on a regional scale. However, the weather station located $25 \mathrm{~km}$ from the Lac La Biche plots was not deemed representative of the forested conditions of the plots given the moderating effect of the lake adjacent to this station, resulting in the Conklin station being selected to look at extreme weather events. The monthly precipitation and minimum and maximum temperature data were used to calculate monthly climate moisture indices (CMI) for the years 1997 to 2007 (Hogg and Hurdle, 1997). Annual CMI values were calculated by summing the monthly CMI values over 12 month periods ending on July 31 of each year to correspond to the pattern of radial growth in aspen (Hogg et al., 2005, 2008).

Although stump sprouts comprised the majority of the aspen regeneration at both study locations, there was a higher incidence of decayed stumps at Lac La Biche relative to Peace River. To assess the amount of stain and decay associated with the stump sprouts at Lac La Biche, stumps with live and dead stump sprouts from the completelycleaned ( 0 stems ha ${ }^{-1}$ residual density) plots were collected. In the laboratory, a series of transverse and longitudinal sections were made through the stump sprout, stump and roots to assess the amount of stain and decay (Fig. 1).

\subsection{Data analyses}

To determine the impact of the treatments on the density and height growth of the aspen and balsam poplar regeneration in 2008 the data were first analyzed as a completely randomized $2 \times$ $3 \times 3$ block factorial design with two levels of location, three levels of residual tree density, and three times of cleaning. The impact of the 


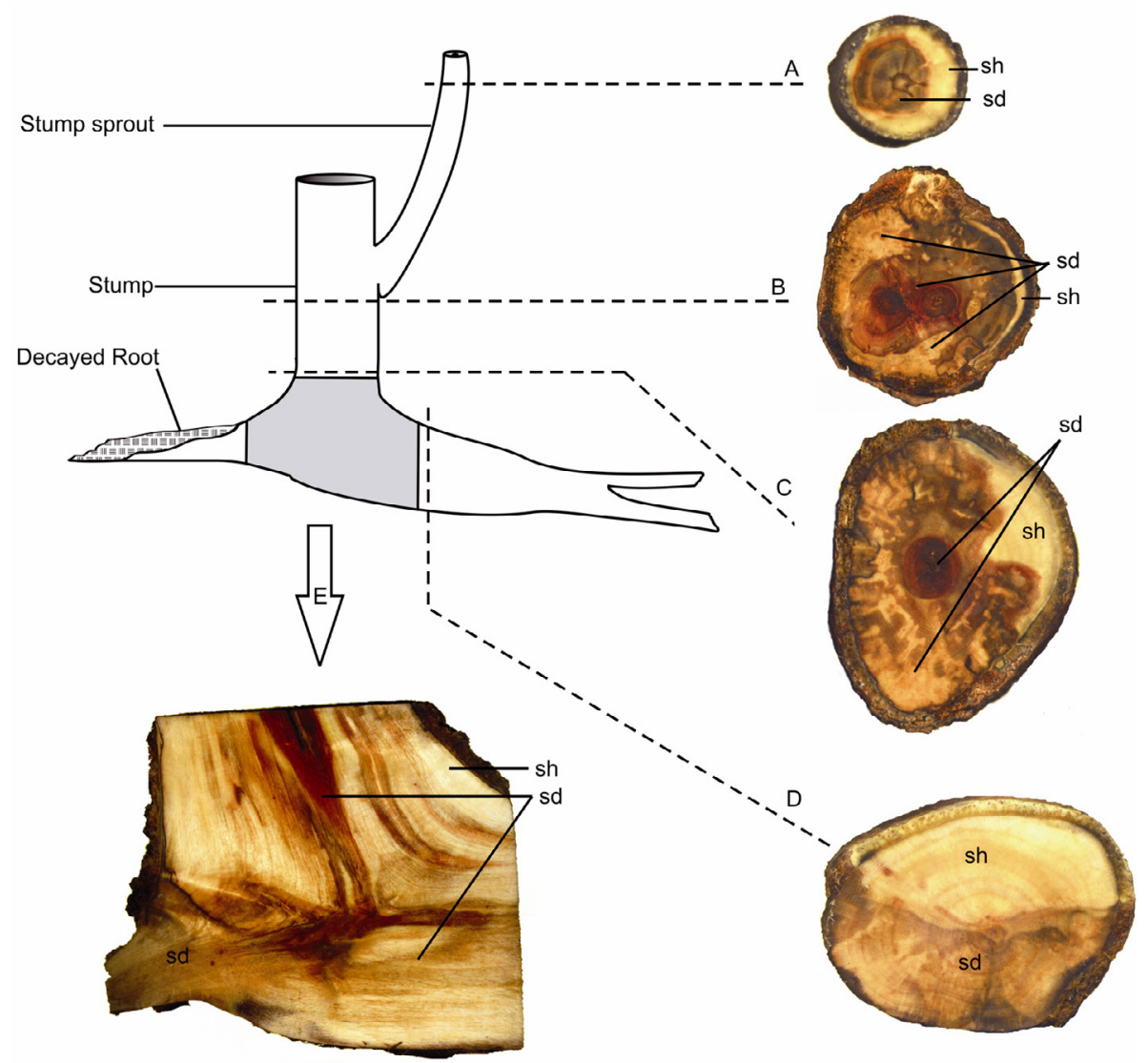

Figure 1. Images of a typical aspen stump sprout from Lac La Biche. Cross-sectional slices are linked to the diagram by dashed lines through the stump sprout (A), the stump at the base of the live sprout (B), at the base of the stump (C), and the large root supporting the stump (D), and the grey shaded area shows a longitudinal section through the stump-root junction (E). The healthy sapwood (sh) and stained and/or decayed sapwood (sd) are indicated.

treatments on the growth of the residual trees was determined by first analyzing the residual tree height in 2008, and the diameter growth between 2004 and 2008 with the 2004 DBH as a covariate using the $2 \times 3 \times 3$ block factorial design described above. For all analyses the absence of 2-way and 3-way interactions with location simplified the statistical models, resulting in only the location, residual tree density, time of cleaning, and residual density-by-time of cleaning interaction as fixed effects, and the replicate cutblocks nested within location as random effects appearing in the model. Where differences in location were observed, the statistical models were then run separately for the Lac La Biche and Peace River data. All statistical analyses were performed using SAS ${ }^{\circledR}$ (SAS Institute Inc., Cary, NC); statistical significance was assessed using $\alpha=0.05$. The assumption of equality of variances was tested using Levene's test and if not met the inequality of variance was modeled. Multiple comparisons were adjusted using Tukey's multiple comparison test.

\section{RESULTS}

\subsection{General observations}

Similar to 2004 , the majority ( $81 \%$ to $89 \%)$ of the aspen regeneration after manual cleaning 5 y post-treatment was com- prised of stump sprouts. However, the aspen stump sprouts at Lac La Biche had very small leaves and commonly broke off at the stump-sprout junction. In contrast, the stump sprouts at Peace River had an overall healthier appearance, and callus growth was observed on the cut surface of many of the stumps.

At Lac La Biche the twig clipping from ungulate browsing on the standing dead and live aspen regeneration was more evident than at Peace River. In contrast, the residual aspen trees in the 500 and 1500 stems ha ${ }^{-1}$ treatment plots at Peace River had large scrape wounds on the stems as a result of ungulates rubbing their antlers. However, these injuries did not appear to have had a large impact on the health of the residual trees.

\subsection{Aspen and balsam poplar regeneration}

Leaving residual aspen trees had a significant effect on the total number of regenerating aspen shoots $5 \mathrm{y}$ post-treatment $(p<0.01)$; this was similar to the results in 2004 (Mulak et al., 2006). However, the density of the aspen regeneration was much lower in Lac La Biche relative to Peace River $(p<0.01)$, and as a result the statistical models were run separately for the two locations. 


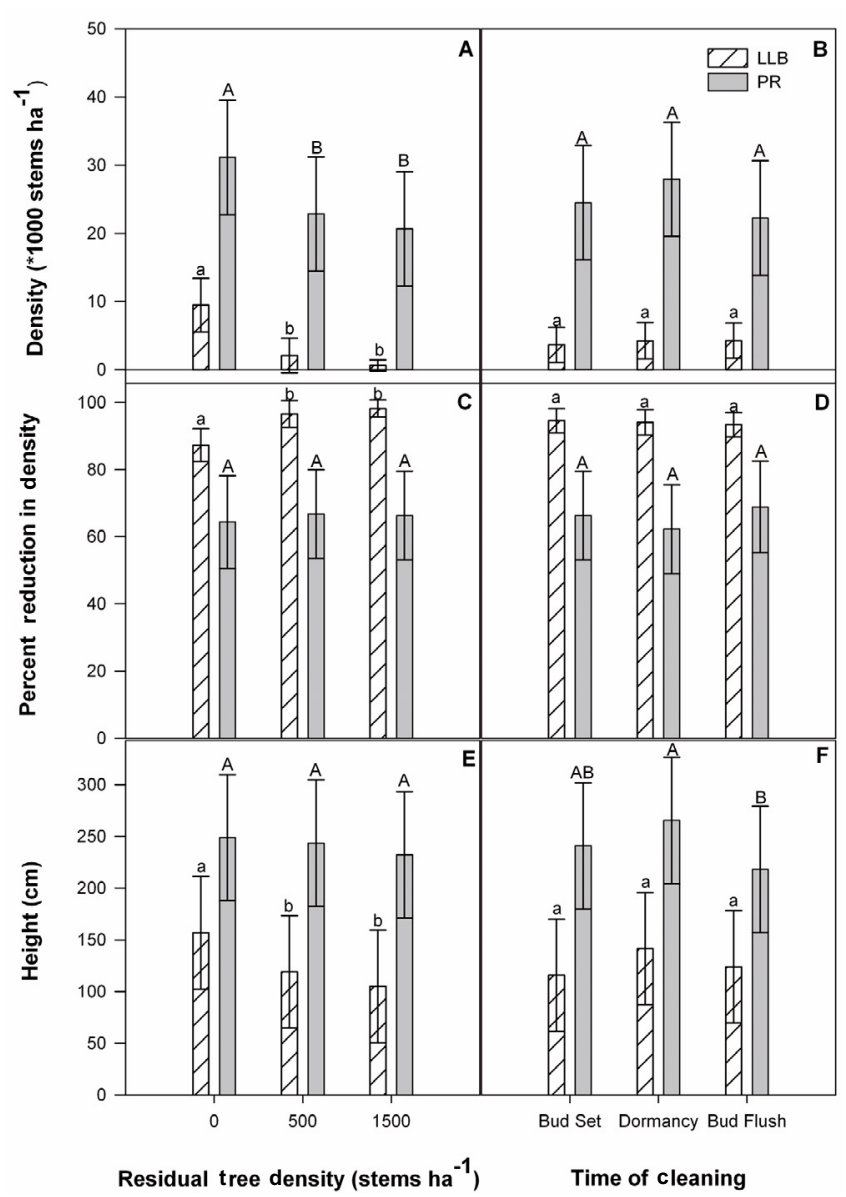

Figure 2. Effects of stem density of residual trees and season of cleaning on the performance of aspen regeneration $5 \mathrm{y}$ post-treatment: the density of aspen regeneration (A, B); percent reduction in density between 2004 and 2008 (C, D); and maximum height of aspen regeneration $(\mathrm{E}, \mathrm{F})$. Bars represent the least square means; error bars represent the $95 \%$ confidence interval of the mean values. Different letters indicate significant differences according to Tukey's multiple comparison test $(p<0.05)$; lowercase letters represent comparisons for Lac La Biche (LLB) and uppercase letters for Peace River (PR).

Five years post-treatment, the completely-cleaned plots contained 9000 stems ha $^{-1}$ in Lac La Biche and 31000 stems $\mathrm{ha}^{-1}$ in Peace River (Fig. 2A); completely-cleaned plots had significantly higher aspen regeneration than the 500 and 1500 stems ha ${ }^{-1}$ plots at both locations $(p<0.01$ for Lac La Biche and Peace River). The time of cleaning did not have any effect on the density of aspen suckers (Fig. 2B; $p=0.92$ for Lac La Biche and $p=0.18$ Peace River).

Although the percent reduction in aspen regeneration between 2004 and 2008 was 87-98\% at Lac La Biche and 64$67 \%$ at Peace River (Fig. 2C), the effect of leaving residual aspen trees on the reduction in regeneration was significant at Lac La Biche (Fig. 2C; $p<0.01$ ) but not at Peace River $(p=0.87)$. At Lac La Biche the partially-cleaned treatments resulted in a greater reduction in the aspen regeneration compared to the completely-cleaned treatments (Fig. 2C; $p=0.01$ for the 500 stems ha ${ }^{-1}$ and $p<0.01$ for the 1500 stems ha $^{-1}$ treatments). The time of cleaning had no impact on the reduction in aspen regeneration at Lac La Biche $(p=0.87)$ and Peace River ( $p=0.32)$ (Fig. 2D).

The aspen regeneration was nearly twice as tall at Peace River $(242 \mathrm{~cm})$ relative to Lac La Biche $(127 \mathrm{~cm})(p=0.01)$. When the models were run separately for the two locations the completely-cleaned treatments at Lac La Biche resulted in taller aspen $(157 \mathrm{~cm})$ relative to the 500 and 1500 stems $\mathrm{ha}^{-1}$ (119 and $105 \mathrm{~cm}$, respectively) residual tree treatments (Fig. 2E; $p=0.01$ ). At Peace River the residual tree density had no impact on the height of the aspen regeneration (Fig. 2E; $p=0.52$ ); the height ranged from 232 to $249 \mathrm{~cm}$. The time of cleaning had no effect on the height of the aspen regeneration at Lac La Biche (Fig. 2F; $p=0.24$ ); however, at Peace River cleaning during bud flush resulted in shorter aspen regeneration relative to the dormancy treatment (Fig. 2F; $p=0.01$ ).

The density of balsam poplar regeneration was three times greater at Lac La Biche relative to Peace River (Fig. 3A; $p=$ $0.04)$. The separate analyses by location indicated that there was no effect of the residual aspen tree density on the density of balsam poplar regeneration for Lac La Biche $(p=0.77)$ and Peace River ( $p=0.78$ ), or time of cleaning on the height of balsam poplar ( $p=0.59$ for Lac La Biche and $p=0.30$ for Peace River). Although there was greater mortality of the balsam poplar regeneration at Lac La Biche compared to Peace River between 2004 and 2008 (Figs. 3A and B), the height of the balsam poplar regeneration was similar between the two locations (Fig. 3C; $p=0.14$ ), and did not vary with the residual aspen tree density $(p=0.13)$, or the time of cleaning $(p=0.29)$. An analysis of the percent reduction in the density of balsam poplar regeneration was not performed as the differences in the sampling intensity of sub-plots between 2004 and 2008 combined with the low mortality at Peace River resulted in an apparent increase in the density of balsam poplar in the 0 and 500 stems ha $^{-1}$ density treatments.

\subsection{Residual aspen tree growth}

The DBH in 2004 and 2008, height in 2008, and basal area $\left(\mathrm{BA} ; \mathrm{m}^{2} \mathrm{ha}^{-1}\right.$ ) for the 500 and $1500 \mathrm{stems} \mathrm{ha}^{-1}$ residual tree density treatments were similar for Lac La Biche and Peace River (Tab. I). The diameter growth of the residual trees between 2004 and $2008(p=0.65)$ and the height in 2008 ( $p=0.43)$ were similar for Lac La Biche and Peace River, and did not vary with either the residual tree density ( $p=0.47$ for the diameter and $p=0.58$ for the height growth), or the time of cleaning ( $p=0.08$ for the diameter and $p=0.72$ height growth).

\subsection{Incidence of insect and diseases associated aspen regeneration}

The aerial survey data indicated that a defoliation event by forest tent caterpillar (Malacosoma disstria Hübner) occurred in the vicinity of the Lac La Biche plots in 2008; however, 


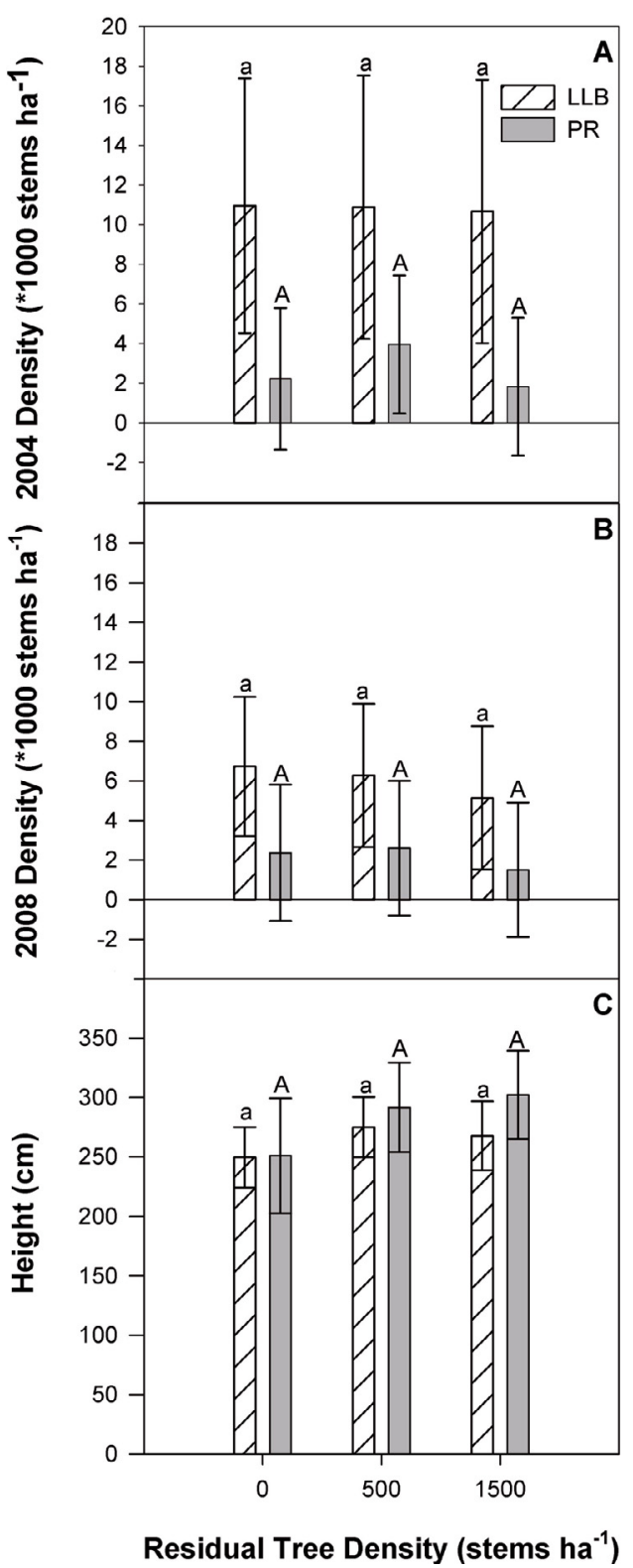

Figure 3. Effects of residual tree density (stems per hectare, stems $\mathrm{ha}^{-1}$ ) on the density of balsam poplar regeneration one year after treatment (2004) (A), density of balsam poplar regeneration 5 y posttreatment (2008) (B), and maximum height (C) of balsam poplar regeneration in 2008 in Lac La Biche (LLB) and Peace River (PR). Bars represent the least square means; error bars represent the $95 \%$ confidence interval of the mean values. Different letters indicate significant differences according to Tukey's multiple comparison test ( $p<0.05)$; lowercase letters represent comparisons for LLB and uppercase for PR.

defoliation was not observed in our treatment plots. Leaf rust caused by Melampsora medusae Thuem. (syn.: Melampsora albertensis Arth.), and aspen shoot blight caused by Venturia tremulae Aderhold. var. grandidentatae (asexual stage $=$ Pollacia americana Ondrej) were observed on the leaves of the aspen regeneration at both study locations in 2008; although not numerically quantified the incidence of aspen shoot blight
Table I. Characteristics of residual aspen trees ( \pm standard deviation).

\begin{tabular}{|c|c|c|}
\hline Tree Characteristic & Lac La Biche & Peace River \\
\hline $\mathrm{DBH}^{\mathrm{a}} 2004(\mathrm{~cm})$ & $4.23 \pm 0.60$ & $5.02 \pm 0.74$ \\
\hline $\mathrm{DBH}^{\mathrm{a}} 2008(\mathrm{~cm})$ & $6.86 \pm 1.07$ & $7.76 \pm 0.93$ \\
\hline Height $^{\mathrm{b}}(\mathrm{m})$ & $7.37 \pm 1.09$ & $7.90 \pm 1.24$ \\
\hline Basal area ${ }^{c}\left(m^{2} h^{-1}\right): 500$ stems ha $^{-1}$ & $2.55 \pm 1.01$ & $2.50 \pm 0.80$ \\
\hline Basal area $\left(\mathrm{m}^{2} \mathrm{ha}^{-1}\right): 1500$ stems ha $^{-1}$ & $5.61 \pm 2.01$ & $5.92 \pm 7.74$ \\
\hline
\end{tabular}

${ }^{a} \mathrm{DBH}$ refers to the tree diameter at breast height $(1.3 \mathrm{~m}) ; n=600$.

${ }^{\mathrm{b}}$ Measured in 2008; $n=180$.

${ }^{c}$ Measured in 2008; $n=30$.

was greater in Peace River. Leaf spot disease on balsam poplar caused by Linospora tetraspora G. Thompson was also observed at both locations.

There were very few new roots attached to the base of the stumps surveyed at Lac La Biche. The majority of the surveyed stumps had epiphytic rhizomorphs (Stanosz and Patton, 1987a, 1990), and the cross-sections and longitudinal-sections had pseudosclerotial plates (zone lines) (Campbell, 1934; LopezReal, 1975) characteristic of infection and decay by Armillaria spp. The cross-sections of live stump sprouts located within $20 \mathrm{~cm}$ of the stump-sprout junction contained stain and/or decay (Fig. 1A). At the base of the stump sprout and the stumproot junction there typically was only a narrow band of healthy sapwood (Figs. 1B and C). The stain and/or decay was extensive in longitudinal view at the stump-root junction (Fig. 1E), which extended a short distance into the large roots supporting the stump (Fig. 1D). The species of Armillaria were not identified, as the two species found in Alberta, A. ostoyae (Romagn.) Herink and A. sinapina Bérubé \& Dessureault (Mallett, 1992) are both associated with a root and butt rot in aspen (Mallett, 1992; Pankuch et al., 2003), and their identification at year five would not provide evidence that either species was the initial colonizing fungus that caused the further decline of the aspen stump sprouts.

\subsection{Climate impacts on aspen regeneration}

The annual CMI values for Lac La Biche and Peace River indicated that two severe drought events occurred in 1998/1999 and 2002 prior to imposing the treatments, and in 2006 two years post-treatment at both Lac La Biche and Peace River. The daily-minimum temperature data indicated that two frost events occurred in the Lac La Biche area in 2005 (Fig. 4A) but not in Peace River (Fig. 4B). Frost occurred on five consecutive days in late May, and again in late June; frost events after mid May were not observed in 2006, 2007 and 2008.

\section{DISCUSSION}

The differences in the amount of mortality and growth of aspen sprouts between the two locations resulted in very different growth trajectories for the aspen regeneration. At Lac La Biche up to $98 \%$ of the aspen regeneration was dead in 


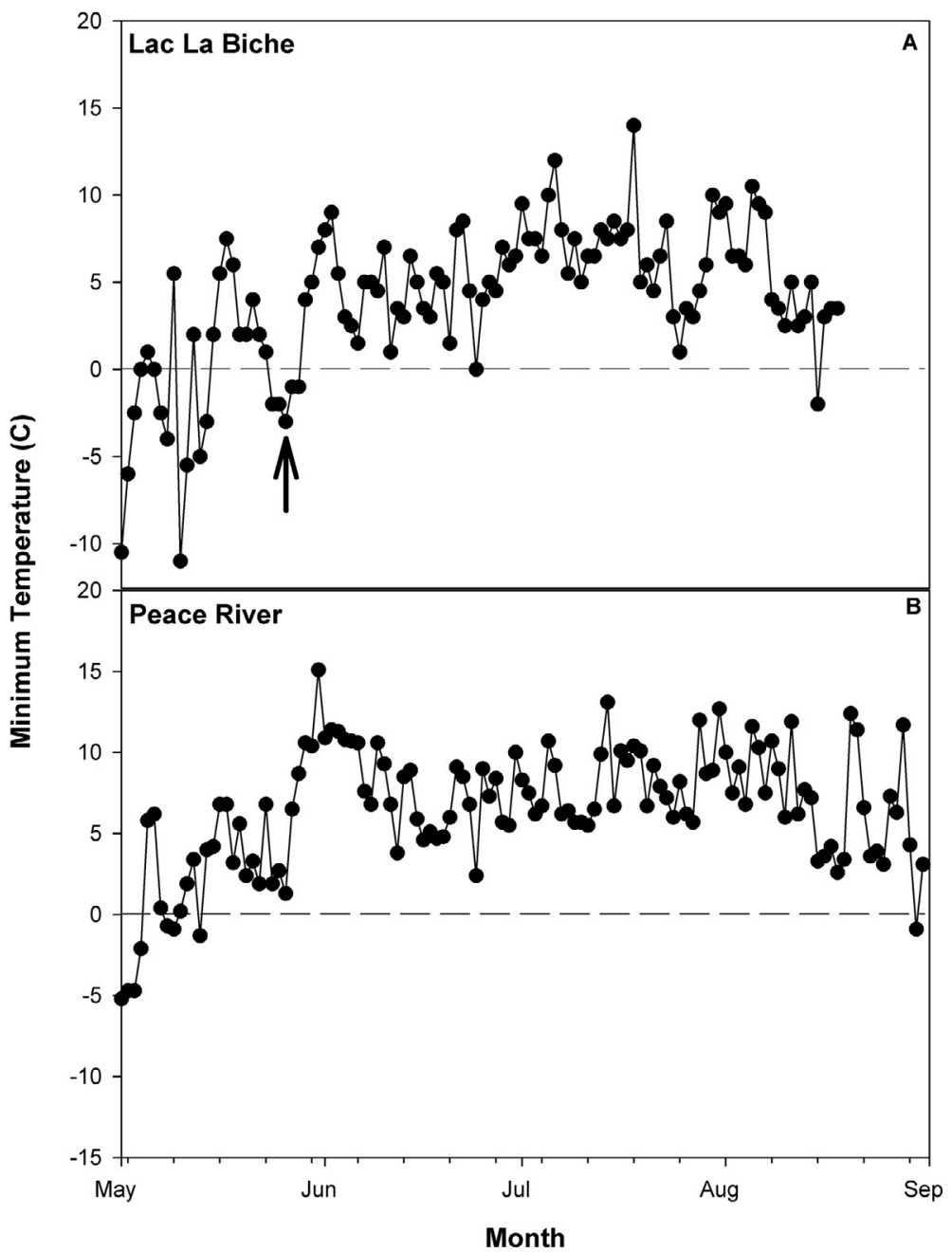

Figure 4. Minimum daily temperatures in May through August 2005 for the Lac La Biche (A; Conklin LO weather station, Environment Canada) and Peace River (B; Peace River weather station, Environment Canada) treatment plots. The arrow in A indicates a late spring frost occurring on five consecutive days.

the partially-cleaned plots 5 years post-treatment compared to $67 \%$ at Peace River. The value of $67 \%$ mortality of aspen regeneration within the first $5 \mathrm{y}$ of stand development approximates the normal rate of self-thinning of dense aspen regeneration (Bella, 1986). The large reduction in the density of aspen regeneration (Fig. 2C) at Lac La Biche suggests that a regional factor weakened the aspen, ultimately leading to the greater mortality at Lac La Biche relative to Peace River. The parallel occurrences of insect defoliation and drought at Lac La Biche and Peace River indicate that these factors did not account for the differences in mortality between the two locations. The late spring frost event in 2005 (Fig. 4A) which occurred at Lac La Biche and not at Peace River is hypothesized to be the inciting factor accounting for the differences in the mortality between the two locations. Minimum air temperatures of $-3{ }^{\circ} \mathrm{C}$ will damage new aspen foliage (Lamontagne et al., 1998; Strain, 1966), and $-6{ }^{\circ} \mathrm{C}$ frosts will kill foliage (Lamontagne et al., 1998). The occurrence of the frost shortly after leaf flush of the aspen would have decreased growth; greater reductions in the radial growth of beech (Fagus sylvatica L.) were reported when frosts lower than $-3{ }^{\circ} \mathrm{C}$ occurred close to the time of bud flush (Dittmar et al., 2006). The residual aspen trees were likely unaffected by the late spring frost, as the majority of frost damage occurs on trees less than $4 \mathrm{~m}$ tall (Ningre and Colin, 2007), and the leaf temperature may be 3 to $4.5^{\circ} \mathrm{C}$ cooler than that of the air at $135 \mathrm{~cm}$ (Shaw, 1954). The balsam poplar regeneration was likely exempt from frost damage as flowering and bud flush occurs later in this species (Maini, 1968), and balsam poplar is more frost resistant than aspen (Krajina et al., 1982).

The expectation was that the frost at Lac La Biche would have a greater impact on the growth of the regeneration in the completely-cleaned plots relative to the partially-cleaned plots, as an aspen canopy can ameliorate the impact of frost in the understory (Groot, 1999; Groot and Carlson, 1996). However, the small size of the residual trees (Tab. I) may not have provided much protection from the frost, as the percent reduction in the density of aspen regeneration was higher in the 
partially-cleaned plots at Lac La Biche (Fig. 2C). It is more likely that the greater reduction in the regeneration density of the partially-cleaned plots was the result of resource limitations of the aspen regeneration under a partial canopy slowing recovery following the frost.

The height of the aspen regeneration at Lac La Biche was about half of that at Peace River (Figs. 2E and F), which is indicative of reduced vigour. The surviving aspen stump sprouts at Lac La Biche had small leaves and were very susceptible to breakage at the stem base, which may be attributed to the extensive stain and decay (Fig. 1). Stump sprouts which comprised the majority of the aspen regeneration at both locations are more susceptible to infection by Armillaria root rot than root suckers (Stanosz and Patton, 1987b). However, the healthy appearance of the stump sprouts at Peace River, and the callus growth observed on the cut surface of the stumps at this location suggests that Armillaria root rot if present was not adversely impacting the growth of the aspen regeneration. Colonization by saprophytic fungi following severe stress often determines whether trees survive or die (Houston, 1992). The stumps and slash associated with the treatment plots were also an ideal substrate for colonization by fungi such as Chondrostereum purpureum (Pers.: Fr.) (Setliff, 2002), which may have played a role in the mortality of the stressed trees (Wall, 1991) at Lac La Biche. The drought in 2006 and ungulate herbivory likely exacerbated the impact of the frost and prevented recovery of the remaining regeneration, as mortality tends to increase when defoliation and drought occur sequentially (Hogg et al., 2005; Houston, 1992). As a result of the poor performance of the aspen at Lac La Biche, balsam poplar when present, became the dominant regeneration on the site as it was able to maintain good height growth similar to the aspen at Peace River (Figs. 2 and 3).

Although previous studies in mature aspen stands suggest that cutting aspen stands during the dormant season results in the greatest density of aspen regeneration (Steneker, 1976), Mundell et al. (2008) determined that the season of harvest had no effect on the density of aspen sucker regeneration in the absence of machine traffic. Given that the treatment plots in the current study were manually cleaned, it is not surprising that the time of cleaning had no effect on the density of aspen regeneration at both study locations in 2004 (Mulak et al., 2006) and 2008 (Fig. 2B). The reduced height growth observed in the bud flush treatment relative to the dormancy treatment at Peace River (Fig. 2F) may be attributed to the reduced root carbohydrate reserves in the spring versus winter season of cleaning (Landhäusser and Lieffers, 2002; Mulak et al., 2006). The mean difference in height between these treatments was $29 \mathrm{~cm}$ in 2004 and $48 \mathrm{~cm}$ in 2008, indicating that the height differences established in the first season of growth were still present in 2008.

The effectiveness of retaining residual trees on reducing the density of aspen regeneration could potentially be increased by either increasing the density of residual aspen, and/or combining this treatment with other methods of vegetation control. Retaining residual aspen densities greater than 1500 stems $\mathrm{ha}^{-1}$ may result in reduced re-sprouting of the aspen; partialcanopy removal decreases the density of aspen regeneration through increased shade (Huffman et al., 1999; Palik et al., 2003; Man et al., 2008) and hormonal suppression of sprouting (Eliasson, 1971). These factors coupled with the colonization of stumps by decay fungi, such as Armillaria spp. and subsequent spread of decay into the roots (Stanosz and Patton, 1990) increases the mortality of aspen regeneration. Retaining residual aspen trees in combination with herbicide treatments such as 2, 4-D amine to cut stumps (Peterson and Peterson, 1995) could decrease the number of stump sprouts. There is also the potential to use $C$. purpureum as a biological control agent of aspen stump sprouts (Peterson and Peterson, 1995); application of $C$. purpureum to aspen stumps reduced the density of stump sprouts by 29 to $88 \%$ (Pitt et al., 1999).

In summary, these results determined that a large stochastic event can influence the outcome of an experiment and its silvicultural interpretations, and emphasize the importance of long term monitoring of field studies. Retaining residual aspen trees to reduce the density of regeneration resulted in two very different stand trajectories 5 y post-treatment. In Peace River, the partially-cleaned treatments suppressed the density of aspen regeneration; however, the regeneration was still too abundant for these treatments to be a viable tool for vegetation control. In contrast, at Lac La Biche the partially-cleaned treatments resulted in nearly complete elimination of the aspen regeneration. It was hypothesized that the stress resulting from the frost event in 2005 and compounded by drought and ungulate herbivory, further reduced the vigour of the aspen and increased the susceptibility of the stump sprouts to colonization by decay fungi such as Armillaria root rot.

Acknowledgements: We thank Kim Stang, Kristine Dahl, Caroline LeCourtois, Kevin Renkema, and Kevin Solarik for assistance in the field. We are grateful to Ted Hogg at the Northern Forestry Centre for help in calculating the climate moisture indices, Aaron McGill at Alberta Sustainable Resource Development and Gabriel Wolken at the University of Alberta for GIS assistance with the insect defoliation data, and Elisabeth Beaubien and Francois Teste for discussions. Funding was provided by the Mixedwood Management Association and the Natural Sciences and Engineering Research Council of Canada (NSERC).

\section{REFERENCES}

Bates P.C., Blinn C.R., and Alm A.A., 1993. Harvesting impacts on quaking aspen regeneration in northern Minnesota. Can. J. For. Res. 23: 2403-2412.

Bella I.E., 1986. Logging practices and subsequent development of aspen stands in east-central Saskatchewan. For. Chron. 62: 81-83.

Campbell A.H., 1934. Zone lines in plant tissues. II. The black lines formed by Armillaria mellea. Ann. Appl. Biol. 21: 1-22.

David A.J., Zasada J.C., Gilmore D.W., and Landhäusser S.M., 2001. Current trends in the management of aspen and mixedwood aspen forests for sustainable production. For. Chron. 77: 525-532.

Dittmar C., Fricke W., and Elling W., 2006. Impact of late frost events on radial growth of common beech (Fagus sylvatica L.) in Southern Germany. Eur. J. For. Res. 125: 249-259.

Doucet R., 1989. Regeneration silviculture of aspen. For. Chron. 65: 23-27. 
Eliasson L., 1971. Growth regulators in Populus tremula III. Variation of auxin and inhibitor level in roots in relation to root sucker formation. Physiol. Plant. 25: 118-121.

Groot A., 1999. Effects of shelter and competition on the early growth of planted white spruce (Picea glauca). Can. J. For. Res. 29: 10021014.

Groot A. and Carlson D.W., 1996. Influence of shelter on night temperatures, frost damage, and bud break of white spruce seedlings. Can. J. For. Res. 26: 1531-1538.

Hogg E.H. and Hurdle P.A., 1997. Sap flow in trembling aspen: implications for stomatal responses to vapor pressure deficit. Tree Physiol. 17: 501-509.

Hogg E.H., Brandt J.P., and Kochtubajda B., 2005. Factors affecting interannual variation in growth of western Canadian aspen forests during 1951-2000. Can. J. For. Res. 35: 610-622.

Hogg E.H., Brandt J.P., and Michaellian M., 2008. Impacts of a regional drought on the productivity, dieback, and biomass of western Canadian aspen forests. Can. J. For. Res. 38: 1373-1384.

Houston D.R., 1992. A host-stress-saprogen model for forest diebackdecline diseases. In: Manion P.D. and Lachance D. (Eds.), Forest decline concepts, American Phytopathological Society, St. Paul, Minnesota, pp. 3-25.

Huffman R.D., Fajvan M.A., and Wood P.B., 1999. Effects of residual overstory on aspen development in Minnesota. Can. J. For. Res. 29: 284-289.

Krajina V.J., Klinka K., and Worrall J., 1982. Distribution and ecological characteristics of trees and shrubs of British Columbia. The University of British Columbia, Faculty of Forestry, Vancouver, British Columbia, $131 \mathrm{p}$.

Lamontagne M., Margolis H., and Bigras F., 1998. Photosynthesis of black spruce, jack pine, and trembling aspen after artificially induced frost during the growing season. Can. J. For. Res. 28: 1-12.

Landhäusser S.M. and Lieffers V.J., 2002. Leaf area renewal, root retention and carbohydrate reserves in clonal tree species following aboveground disturbance. J. Ecol. 90: 658-665.

Lopez-Real J.M. and Swift M.J., 1975. Formation of pseudosclerotia (zone lines) in wood decayed by Armillaria mellea and Stereum hirsutum, II. Formation in relation to moisture content of wood. Trans. Br. Mycol. Soc. 64: 473-481.

Maini J.S., 1968. Silvics and ecology of Populus in Canada. In: Maini J.S. and Cayford J.H. (Eds.), Growth and utilization of poplars in Canada, For. Branch Publ. 1205, Canada Dept. For. Rural Devel., Ottawa, Ontario, pp. 20-69.

Mallett K.I., 1992. Armillaria root rot in the Canadian prairie provinces. Inf. Rep. NOR-X-329, Forestry Canada, Northwest Region, Northern Forestry Centre.
Man R., Kayahara G.J., Rice J.A., and MacDonald G.B., 2008. Elevenyear responses of a boreal mixedwood stand to partial harvesting: light, vegetation and regeneration dynamics. For. Ecol. Manage. 255: 697-706.

Mulak T., Landhäusser S.M., and Lieffers V.J., 2006. Effects of timing of cleaning and residual density on regeneration of juvenile aspen stands. For. Ecol. Manage. 232: 198-204.

Mundell T.L., Landhäusser S.M., and Lieffers V.J., 2008. Root carbohydrates and aspen regeneration in relation to season of harvest and machine traffic. For. Ecol. Manage. 255: 68-74.

Ningre F. and Colin F., 2007. Frost damage on the terminal shoots as a risk factor of fork incidence on common beech (Fagus sylvatica L.). Ann. For. Sci. 64: 79-86.

Palik B., Cease K. Egeland L., and Blinn C., 2003. Aspen regeneration in riparian management zones in northern Minnesota: effects of residual overstory and harvest method. N. J. Appl. For. 20: 79-84.

Pankuch J.M., Blenis P.V., Lieffers V.J., and Mallett K.I., 2003. Fungal colonization of aspen roots following mechanical site preparation. Can. J. For. Res. 33: 2372-2379.

Peterson E.B. and Peterson N.M., 1995. Aspen managers' handbook for British Columbia. Canada-British Columbia Partnership Agreement, FRDA II. FRDA Report No. 230, Victoria, B.C., Canada.

Pitt D.G., Dumas M.T., Wall R.E., Thompson D.G., Lanteigne L., Hintz W., Sampson G., and Wagner R.G., 1999. Chondrostereum purpureum as a biological control agent in forest vegetation management. I. Efficacy on speckled alder, red maple, and aspen in eastern Canada. Can. J. For. Res. 29: 841-851.

Setliff E.C., 2002. The wound pathogen Chondrostereum purpureum, its history and incidence on trees in North America. Aust. J. Bot. 50: 645-651.

Shaw R.H., 1954. Leaf and air temperatures under freezing conditions. Plant Physiol. 29: 102-104.

Stanosz G.R. and Patton R.F., 1987a. Armillaria root rot in Wisconsin aspen sucker stands. Can. J. For. Res. 17: 995-1000.

Stanosz G.R. and Patton R.F., 1987b. Armillaria root rot in aspen stands after repeated short rotations. Can. J. For. Res. 17: 1001-1005.

Stanosz G.R. and Patton R.F., 1990. Stump colonization by Armillaria in Wisconsin aspen stands following clearcutting. Eur. J. For. Pathol. 20: $339-346$.

Steneker G.A., 1976. Guide to the silvicultural management of trembling aspen in the prairie provinces. Inf. Rep. NOR-X-164, For. Can., North. For. Cent., Edmonton, Alberta.

Strain B.R., 1966. Effect of a late spring frost on radial growth of variant quaking aspen biotypes. For. Sci. 12: 334-337.

Wall R.E., 1991. Pathological effects of Chondrostereum purpureum in inoculated yellow birch and beech. Can. J. Plant Pathol. 13: 81-87. 